Article

\title{
Patterns, Costs, and Implications of Police Abuse to Citizens' Rights in the Republic of Zimbabwe
}

\author{
Ishmael Mugari ${ }^{1}$ and Emeka E. Obioha ${ }^{2, *}$ \\ 1 Department of Safety and Security Management, Tshwane University of Technology, Pretoria 0001, \\ South Africa; ishiemugari@gmail.com \\ 2 Department of Social Sciences, Walter Sisulu University, Mthatha 5099, South Africa \\ * Correspondence: emekaobioha@gmail.com; Tel.: +27-790-815-604
}

Received: 30 May 2018; Accepted: 9 July 2018; Published: 16 July 2018

\begin{abstract}
The Police play a key role in maintaining law and order and safeguarding the security of the nation and its citizens. To enable them to discharge their constitutional mandate, they are entrusted with powers such as the power to arrest, detain, search, and to use force. However, police officers have often abused these powers with serious consequences on the image and operations of the organisation. The media is often inundated with news on unlawful arrests, arbitrary search and seizure, unlawful methods of investigations, and the excessive use of force. It is without a doubt that these incidences of abuse of powers and functions by the police come at a price. This study, a survey conducted with 91 respondents ( 83 members of public and 8 police officers) in 2 policing districts in Zimbabwe reveals wanton violation of human rights, police brutality, and the abuse of power which have resulted in both social and economic costs to the Police service and government of Zimbabwe through Civil suits against the police. Among other issues, training and decisiveness in dealing with the implicated police officers were viewed as the most effective ways for dealing with police abuse of power.
\end{abstract}

Keywords: human right; power; police; community; abuse; Zimbabwe

\section{Introduction}

The Police Service is an important arm of the government, charged with the responsibility of protecting the lives and property of people, criminal investigations, and maintaining law and order. Of all governmental functions, the policing function is arguably the most visible and the most immediate, and the most intimately involved function with the well-being of individuals in communities (Skolnick 1999, p. 7). Regardless of the situations in which the police find themselves in, it is their duty to execute their powers and functions in accordance with the law, and with due respect to fundamental human rights. However, the vast powers that have been bestowed upon the police have created a breeding ground for police abuse of powers and functions. Most of the police powers, which are not available to ordinary citizens, have a bearing on the fundamental rights of citizens. These powers are clearly outlined in the Criminal Procedure and Evidence Act, Chapter 9:07 (Republic of Zimbabwe 1980). The grounds on which to exercise these powers, as well as the limits of these powers, are also outlined in this Act. The powers have to be exercised within the prescribed limits of the law, for the purpose of law enforcement and with due respect to the fundamental human rights. Abuse of these police powers and functions takes various forms such as unlawful arrests; unlawful methods of investigation, police torture, indiscriminate use of excessive force, and ill-treatment of persons in police custody.

More often, the Zimbabwe Republic Police (Z.R.P) has had to contend with allegations of unlawful arrests, excessive use of force, and partisan policing, and this could be a possible indication of the 
questionable execution of the powers they possess. Zimbabwe is a developing country located in Southern Africa. The Z.R.P is a centrally controlled police organisation, with its headquarters in the capital city, Harare, and is headed by the Commissioner General of Police. The organisation is established in terms of Section 219 of the Constitution of Zimbabwe which provides that; "There is a police service which is responsible for (a) Detecting, investigating and preventing crime; (b) Preserving the internal security of Zimbabwe; (c) Protecting and securing the lives and property of the people; (d) Maintaining Law and Order; and (e) Upholding this constitution and enforcing the law without fear or favour" (Republic of Zimbabwe 2013a). The policing landscape in Zimbabwe was shaped by the colonial legacy. Zimbabwe attained her independence from British colonial rule in 1980. Prior to independence, policing was mainly done within the purview of fighting terrorism and insurgency, and a state of emergency had been proclaimed since 1965. Chihuri (2015) notes that, as a result of the state of emergency and the threat of terrorism, there were serious human rights violations by the police in the pre-independence era. It is important to highlight that the state of emergency continued for more than a decade after independence (Chihuri 2015). Colonial legacies and political turmoil post-independence continue to affect the relationship between the police and the public. Our findings provide a critical evaluation of the implications of the police abuse of power on the well-being of citizens and their perception of police.

\section{International and National Laws Pertinent to Human Rights Violations}

In order to prevent police abuse of power, several treaties and conventions have been signed on the global and regional scale. The most notable treaties are the Universal Declaration Human Rights (UDHR), the International Covenant on Civil and Political Rights (ICCPR), the Code of Conduct for Law Enforcement Officials, the Convention against Torture (CAT), and the Code of Conduct for Law Enforcement Officials. Moreover, most of the important provisions of the international treaties and conventions have been incorporated into the country's domestic laws. To this end, any act of abuse of power by the police in Zimbabwe will have international ramifications.

Much of the human rights violations emanate from unlawful arrests, and an unlawful arrest happens when the police, without lawful justification, restrain the liberty of citizens during arrest and imprisonment (Feltoe 2012, p. 90). Article 9 of the International Covenant on Civil and Political Rights (ICCPR) clearly outlaws illegal arrest when it provides that "everyone has the right to liberty and security of a person. No one shall be subjected to arbitrary arrest and detention. No one shall be deprived of his liberty except on such grounds and in accordance with such procedure as established by law". Police should therefore never infringe on the citizens right to personal liberty through unlawful arrest. On the regional front, the African Charter on Human and People's Rights outlaws unlawful arrest in Article 6, which provides that "every individual shall have the right to liberty and to the security of his person. No one may be deprived of his freedom except for reasons laid down by law. In particular, no one may be arbitrarily arrested or detained". These important provisions have also been incorporated into the Constitution of Zimbabwe. Specifically, section 49 of the constitution provides that every person has a right not to be detained without trial and the right not to be deprived of their liberty arbitrarily without just cause.

Several far-reaching judgements have been passed by the Zimbabwean Courts in relation to the abuse of the right to personal liberty through unlawful arrest. In the case of Allan v Minister of Home Affairs and Another, in which the plaintiff had sued the police of unlawful arrest, it was held that " ... it is essential for any person entrusted with the power of arrest to exercise the power only in cases of urgency and necessity" (Republic of Zimbabwe 1985). Similarly, the Supreme Court of Zimbabwe summed up the importance of the right to personal liberty in the case of Minister of Home Affairs and Another v Bangajena, where it was stated that "the deprivation of personal liberty is an odious interference and has always been regarded as serious injury" (Republic of Zimbabwe 2000a).

Torture is also a particularly serious violation of human rights and is strictly prohibited by international law in the following instruments, among others: the UDHR, ICCPR, the Code of Conduct 
for Law Enforcement Officials, and the CAT. Article 1 of the CAT defines torture as follows: "Any act by which severe pain or suffering whether physical or mental, is intentionally inflicted on a person for such purposes as obtaining from him or a third person information or a confession, punishing him for an act he or a third person has committed or is suspected to have committed, or intimidating or coercing him or a third person, or for any reason based on discrimination of any kind, when such pain or suffering is inflicted by or at the instigation of a public official or other person acting on an official capacity" (United Nations Convention Against Torture and Other Cruel, Inhuman or Degrading Treatment or Punishment (United Nations 1984)). The definition of torture is all-encompassing and includes assault of suspects and several other methods used to unlawfully obtain confessions from suspects. Supporting the view for the abolition of torture, Jessberger $(2005$, p. 1063) suggests that the dignity of the human being is inviolable under any circumstances, and torture is the most severe violation of human dignity. Malaba, J. summed it up in the case of Mapuranga v Mungate when he said, "every person's body is however sacred and inviolable. No other man has a right to meddle with it in the slightest manner except in the circumstances prescribed by the law. The person assaulted is entitled to damages even though he suffered no severe pain or any damage at all other than the insult of having his bodily integrity interfered with" (Republic of Zimbabwe 1997a).

In the case of Karimazondo and Another v Minister of Home Affairs and Another, (Republic of Zimbabwe 2001) the plaintiffs were both arrested on allegations of murder but the charges were subsequently dropped. The plaintiffs were subjected to torture whilst in custody and they suffered long-lasting physical and psychological effects. The learned judge said, "the actions of the police, in this case, were in flagrant and disregard of the rights of the plaintiffs ... the brutality and callousness with which the assaults were perpetrated on the first plaintiff instils in any right-thinking person a sense of horror and shock ... The unlawful and inhuman treatment to which the first plaintiff was subjected was, in my view totally unnecessary, vindictive and malicious." In the Karimazondo case above, it was ironical that the first plaintiff was a member of the Zimbabwe Republic Police whilst the second plaintiff was his wife. One may infer that the torture could have been worse had they not been dealing with one of their own.

Abuse of police power can also manifest through indiscriminate use of excessive force and firearms. The constitutional duty of preserving peace and maintaining law and order sometimes necessitates the use of force. Article 3 of the UN Code of Conduct for Law Enforcement Officials (UNCCLEO) provides that law enforcement officials may use force only when strictly necessary and to the extent required for the performance of their duties. To this end, use of force by the police should be guided by the three principles, namely, legality, proportionality, and necessity. The Southern African Regional Police Chiefs Cooperation (SARPCCO) Code of Conduct also spells out a minimum set of standards for policing standards in the Southern African Region, and an important consideration among these standards is the management of police use of force. The provisions of the UNCCLEO and the SARPCCO Code of Conduct have been incorporated in the Z.R.P's public order strategy. Whilst inclusion of the provisions is a positive step, there could be challenges to implementation. There are situations, however, in which police have used excessive force, sometimes resulting in the loss of innocent lives. In 1998, seven people lost their lives as the Z.R.P tried to deal with nationwide food riots that had gripped Zimbabwe (Chinaka 2000). In the year 2000, thirteen human lives were lost during a football match when police officers fired tear smoke into a restive stadium crowd (Vhiriri 2011). In 2012, one person died whilst others sustained serious injuries when police in Shamva assaulted residents after a suspected case of theft (Kachere 2012). All these incidences point to the excessive use of force by the police with far-reaching consequences.

A decided case which highlights the unwarranted use of firearms is that of Musadzikwa v Minister of Home Affairs and Another (Republic of Zimbabwe 2000b). In this case, police had used automatic weapons to quell a riot and an innocent passer-by was injured in the process. The court found that it was not conducive to harmonious community relations for the police force to unleash its members onto an urban shopping centre located in a centre of a densely suburban residential area armed with FN 
rifles (A Light Automatic Rifle and a battle rifle designed by Belgian small armsdesigners Dieudonné Saive and Ernest Vervier and manufactured by FN Herstal). The court also highlighted that whilst police were entitled to use force and firearms to disperse the rioters, it was unreasonable to use FN rifles and so they were liable.

Another manifestation of abuse of police power is the ill-treatment of persons in police custody. Persons in police custody should be treated in a humane manner as they are considered to be innocent until proven guilty by competent courts of law. On the international arena, the Body of Principles for the Protection of Persons under any form of Detention or Imprisonment prohibits the torture of persons under detention and also provides for the detainees' rights to humane treatment. Importantly, Section 50 of the Constitution of Zimbabwe provides for the rights of detained persons. Amongst the constitutional rights relating to detained persons are the $48 \mathrm{~h}$ limit for the period of detention; the right to consult a legal practitioner, medical practitioner and relatives; and the right to be informed of the reason of arrest at the time of arrest.

Despite the relevant legal provisions, the Z.R.P has had to contend with allegations of the ill-treatment of detained persons. For example, according to the Human Rights Watch (2008, p. 2), police detain accused persons beyond the forty-eight-hour statutory limit, show contempt for court proceedings and frequently deny detainees access to legal representation or relatives. In their report on policing in Zimbabwe, The International Bar Association Human Rights Institute (International Bar Association 2007) highlighted that police routinely disregard basic rights of detainees, such as the free access for detainees to their lawyers, access to family members, medical personnel, and courts. All these actions are manifestations of police abuse of power. Whilst these allegations were more pronounced before the promulgation of the new constitution in 2013, there seems to be an improvement in the way in which the police handles detained persons. This could possibly be due to the inclusion of specific rights of accused persons in the new constitution. Despite the improvement, the Zimbabwe Human Rights Non-Governmental Organisation (NGO) Forum (2015) notes that the police have, on several occasions, arbitrarily detained human rights defenders and pro-democracy activists in the absence of reasonable suspicion.

\section{Study Aim and Implications}

Given the important role that the police play in the wellbeing of the citizens, it is important to analyse the nature of the relationship that exists between the police and the public. Where such relationship is strained, chiefly due to police excesses, there is a need for critical evaluation of the implications of police excesses upon the citizens. Such critical evaluation necessitates the adoption of correct prescriptive measures to deal with police excesses. To this end, this study sought to: (1) assess the implications of police abuse of power; (2) to explore the current internal mechanisms for dealing with incidents of police abuse of powers and functions; and (3) to recommend appropriate prescriptive measures to deal with police abuse of power. Key findings to this study reveal that the police abuse of power has a significant impact on police public relations, with the loss of respect for the police, withdrawal of public support, fear of the police and the loss of lives or injuries to innocent civilians topping the list of implications of police abuse. Civil suits against the police, with both cost and image implications on the police organisation, is also another notable implication. Whilst the police organisation has internal mechanisms to deal with incidents of police misconduct, the mechanisms seem inadequate, chiefly due to a lack of transparency. Training and decisiveness in dealing with implicated police officers are among the significant measures that were recommended by the respondents.

Whilst the data was gathered during a period when the political environment was polarised, and when allegations of police abuse of power were more pronounced, the findings will help to shape police policy in the new political dispensation. The thrust of the new administration in Zimbabwe is to improve the police public relations, which is widely viewed to have been strained due to the police excesses that characterised the previous administration. 


\section{Materials and Methods}

\subsection{Population, Sample and Data Collection}

The sample population integrated members of the public from diverse professional backgrounds ranging from education, other government departments, legal field, farmers, transport operators, and non-governmental organisations. They were drawn from two policing districts, namely, Bindura and Mount Darwin, the former being an urban police district while the latter is a rural police district. A total of 83 members of the public participated, out of which 73 provided data through completion of the questionnaire, while an in-depth interview was conducted on the other 10 respondents. A sample of 8 police officers was invited to provide data through in-depth interviews. A close-ended questionnaire was used. Respondents were asked on the level of impact of police abuse of powers and they were asked to indicate on a scale which had three labels, namely, no impact, lesser impact and greater impact. Respondents were also asked to rate the police service in terms of quality and they responded by ticking on a scale which ranged from very poor to very good. Respondents were also asked to rate strategies that were provided by the researcher and they indicated their response on a scale which had labels 1 to 5, denoting least effective to most effective, respectively. Quantitative data from the questionnaire were fed into Statistical Package for the Social Sciences (SPSS) version 16 for analysis, and where appropriate the data was further summarised. A semi-structured interview guide was used with the aim of obtaining information on the effects of the police abuse of power, as well as the possible remedies. Depending on the background of the respondents, further probing was done where necessary. Useful information was also obtained from various articles on policing and abuse of power. Relevant case law was also looked at to show how police misconduct was handled by the courts of law. Data for this paper was generated within a span of two years (2013-2014) when the main interviews were conducted. Further, follow up short time research visits to the study locations were undertaken in 2015, 2016, and 2017 to update the data where necessary. These visits helped the researchers in obtaining more clarifications on the subject matter and cleaning the data, especially the qualitative aspect. All the required data used for this paper were fully collected and analysed before the fall of the Robert Mugabe government in 2017. The analysis contained in the study is therefore limited to the period before the present regime headed by Mr Emmerson Mnangagwa.

\subsection{Ethical Consideration}

Even though this research was community-based study, rather than an institutional one, the researchers ensured that all the protocols were observed before the commencement of data collection. The researchers gained entry into the population with an introduction letter from the university department (supervisor), which clearly indicated the purpose of the data collection as a purely research and academic exercise. All participants were asked to declare their willingness to participate voluntarily with an absolute right to withdraw from the process at any point in time if they wish. Respondents were also assured of the confidentiality of their data and, in this regard, no names would appear on both the questionnaires and the in-depth interview responses booklet. All the sources that were cited by the researcher were acknowledged within the text and in the list of references. All respondents took part in this study based on their individual capacities as adults of sound mind from whom the researchers obtained consent before commencement of the interviews.

\subsection{Study Limitations}

The major limitation of this study lies in the small population sample. Findings from a sample of 83 respondents from two policing district may not be reflective of the general views of the majority of Zimbabweans. The small sample could be attributed to the polarised political environment that characterised the period before the new political dispensation, wherein citizens were not free to criticise key government arms such as the police. Moreover, the majority of the police officers were not willing to participate in this study for fear of possible persecution. For the few police officers who were willing 
to participate in this study, the majority of them were defending police actions, which could have negatively affected objectivity. However, despite these limitations, this study highlights the challenge of human rights violations in Zimbabwe, an area which has not been widely studied.

\section{Results and Discussion}

\subsection{Implications of Police Abuse of Powers and Functions}

The study (Table 1) revealed that police abuse of powers has a greatest implication on community policing and police-community relationship. Loss of respect for the police (98.6\%), withdrawal of public support (94.3\%), and fear of the police (91.4\%) are directly linked to community policing and police-public relationship. Loss of lives and injuries to innocent citizens were viewed as impacts by $94 \%$ of the respondents. Reduced morale among honest officers and spiral violence were considered as effects by $76.1 \%$ and $73.4 \%$, respectively.

Table 1. The response on the implications of police abuse of powers and functions, $N=73$.

\begin{tabular}{ccc}
\hline Effect & No Impact & Significant Impact \\
\hline Civil suits against the police & $10.3 \%$ & $89.7 \%$ \\
Withdrawal of public support & $5.7 \%$ & $94.3 \%$ \\
Loss of respect for the police & $1.4 \%$ & $98.6 \%$ \\
Loss of lives of innocent civilians & $6.0 \%$ & $94.0 \%$ \\
Injuries to innocent civilians & $6.0 \%$ & $94.0 \%$ \\
Reduced morale amongst honest officers & $23.9 \%$ & $76.1 \%$ \\
Spiral violence & $26.6 \%$ & $73.4 \%$ \\
Fear of the police & $8.6 \%$ & $91.4 \%$ \\
\hline
\end{tabular}

\subsection{Effects of Police Misconduct on Community Policing and Police Community Relations}

Three of the effects that were covered on the questionnaire for the public hinged on community policing. These were the withdrawal of public support, loss of respect for the police, and fear of the police by the public. Fear of the police was considered by interview respondents as the greatest effect of police abuse of powers and functions. Some of the police officers who were interviewed indicated that complainants may even fail to report their cases due to fear of the police. Feltoe (1997) highlighted that fear of the police was visibly noticed soon after independence and up to the time when the Service Charter was launched by the Z.R.P. During this period policing was being done in the environment of a state of emergency.

Police abuse of powers also leads to the loss of respect for the police. The community expects to be treated in a humane manner by the police for them to cooperate with the police. The scenario is the same as that of a family set up, in which an abusive father will not command respect from his family. Respondents also indicated that police abuse of powers leads to withdrawal of public support. The Z.R.P does not have all the required resources to carry out its constitutional mandate. The public often comes in with resources such as motor vehicles, computers, and even the construction of police stations. Any behaviour by the police that is unpalatable to the public will result in the withdrawal of such important support. Community policing is a concept that is derived from democratic policing principles. Police officers derive their legitimacy from the community, hence, they should be accountable to the community. Skolnick (1999) highlights that the police forces are not supposed to be insular, self-contained, or cut from the communities from which their powers are derived. On the official launch of the community policing on 13 March 1983 in Zimbabwe, the then Prime Minister Robert Mugabe had this to say, "we must underscore the point that effective policing must derive from and flourish on the goodwill and cooperation with the whole community from whom any police force derives its legitimacy. The police must strive to educate the masses so that they identify the objectives and functions of the police as their own, in turn, they must feel that 
the people's needs and aspirations are also their own" (Chihuri 2003). This was an important call for police officers to foster good relations with the public. Abuse of powers and functions by the police will thus destroy the whole essence of community policing. Police officers will become the enemies of the public, yet both are expected to share a symbiotic relationship.

\subsubsection{Loss of Lives and Injuries to Innocent Civilians}

Loss of lives and injuries to innocent civilians may also be a result of the excessive use of force by the police. In the Mashonaland Central Province, in which the two districts are located, police recruits assaulted 38 residents in Shamva, in an incident that was viewed as the unnecessary inflicting of injuries on civilians (Kachere 2012). In March 2012, one person died and several others were seriously injured when the police used excessive force to carry out an arrest (Kachere 2012). The food riots in the year 1998 left 7 people dead and several others were injured during the commotion (Chinaka 2000). Some innocent civilians sued the police for the injuries they sustained and the notable case is that of Musadzikwa v Minister of Home Affairs and Another (Republic of Zimbabwe 2000b). In this case, the plaintiff was shot by the police's stray bullet and he won the civil suit. Activists from the Women of Zimbabwe Arise (WOZA) were injured on several occasions during their clashes with the police yet they were holding peaceful demonstrations (Gumbo 2012).

\subsubsection{The Euphoria of Retaliation among the Civilian Population}

Whilst $73.4 \%$ of the questionnaire respondents cited spiral violence as an impact, the majority of the interview respondents also indicated that citizens may retaliate in instances where police use indiscriminate force. In an incident that shocked residents of Shamva in 2012, one person died and eight others were seriously injured when police brutally assaulted members of the public after a theft case. Residence showed their displeasure by demonstrating at the police station, only to be calmed down by the provincial political leadership and the provincial police command (Kachere 2012). Though incidences of retaliation may be few, given the heavy-handedness with which they are likely to be dealt with by the police, disastrous consequences are usually the end result. Omar (2012) in his study of the security sector reform in Egypt, highlighted that Egypt's revolution of January 2011 was sparked by the brutality of the deposed president Mubarak's police and security forces.

\subsubsection{Civil Suits against the Police Authority}

Civil suits against the police authority were considered an impact by $89.7 \%$ of the questionnaire respondents and interview respondents also indicated that civil suits have several other undesirable consequences in terms of the costs and image of the organisation. Some of the respondents were not, however, aware of the procedure for filing civil suits, hence, they could not consider civil suits against the police as an impact. Respondents were asked on whether they were aware of the procedure for filing civil suits against the police. Table 2 shows that $69.4 \%$ of the respondents were not aware of the procedure for filing civil suits against the police. It shows that if more people were aware of the procedure, then civil suits could have been one of the major impacts of police abuse of power.

Table 2. The response on awareness of the procedure for filing civil suits against the police.

\begin{tabular}{ccc}
\hline Response & Frequency & Percent \\
\hline Yes & 22 & 30.6 \\
No & 50 & 69.4 \\
Total & 72 & 100.0 \\
\hline
\end{tabular}

Four of the police officers also considered civil suits to be among the major effects of police abuse of powers and functions. They highlighted that precious time will be lost as the legal services department attempts to defend the implicated police officers. One of the police officers also indicated 
that the implicated police officers will also be called to attend court and valuable manpower will be lost in the process. Most of the civil suits that were reviewed in this study emanated from unlawful arrest, unlawful detention and unlawful searches.

Consequences of civil suits may be visible in the sense that the civil cases are documented in the law reports and anyone can access the law reports. Civil suits often culminate in larger settlements in favour of plaintiffs (McCulloch and Palmer 2003, p. 1). Stressing on the nature of damages for civil suits, the Supreme Court, in the case of Minister of Home Affairs and Another v Bangajena (Republic of Zimbabwe 2000a) held that damages for unlawful arrest and imprisonment should be exemplary and punitive to deter would-be offenders. In the same vein, the Z.R.P has lost large sums of money due to successful civil suits against the police. Table 3 shows some of the damages that were awarded after victims of police abuse of powers had sued the police. Most of the civil suits against the Z.R.P are published in the media at the time when the suits are filed, during the proceedings and when the final judgements are given. This tarnishes the image of the organisation, especially when judgements are eventually given in favour of the plaintiffs.

Table 3. The civil suits and quantum of damages and costs.

\begin{tabular}{ccc}
\hline Case & Reason for Civil Suit & Quantum of Damages \\
\hline $\begin{array}{c}\text { Kotha v Zvada (1997b) } \\
\text { Home Affairs and Others (2001) }\end{array}$ & Unlawful arrest and detention & Z\$20,000 \\
\hline $\begin{array}{c}\text { Mugwagwa v Minister of Home Affairs } \\
\text { and Others (2004) }\end{array}$ & $\begin{array}{c}\text { Unlawful arrest, unlawful } \\
\text { detention, and torture }\end{array}$ & Assault by police officers $\$ 300,000$ \\
\hline $\begin{array}{c}\text { Nyandoro v Minister of Home Affairs and } \\
\text { Another (2010) }\end{array}$ & Assault by police officers & US\$5000 \\
\hline $\begin{array}{c}\text { Muskwe v Minister of Home Affairs and } \\
\text { Others (2013b) }\end{array}$ & Unlawful arrest and detention & US\$1500
\end{tabular}

\subsubsection{Public's Perception of the Z.R.P's Service Delivery}

Despite some of the shortcomings on the part of the Z.R.P, findings reveal that the public has maintained some confidence in the Z.R.P. Table 4 shows that $34.7 \%$ of the respondents rated the Z.R.P service as average, $25 \%$ considered their service as good, whilst $12.5 \%$ considered the service to be very good. Only $27.8 \%$ of the respondents considered the Z.R.P service to be either poor or very poor.

Table 4. The response on the rating of service offered by the Zimbabwe Republic Police (Z.R.P).

\begin{tabular}{ccc}
\hline Response & Frequency & Percent \\
\hline Very poor & 7 & 9.7 \\
Poor & 13 & 18.1 \\
Average & 25 & 34.7 \\
Good & 18 & 25.0 \\
Very good & 9 & 12.5 \\
Total & 72 & 100.0 \\
\hline
\end{tabular}

A further analysis by the area of residence (Table 5) reveals that slightly below half (48.3\%) of the respondents from Mt. Darwin viewed police service as mainly good, while 32.4\% from Bindura view the police service as mainly good. The study also reveals that those in the age group of 55 years and above rate the police service as either average $(33.2 \%)$ or mainly good $(66.7 \%)$. Interestingly, those who have stayed for a longer period of at least 7 years in the two districts are inclined to the opinion that service delivery is mainly good $(51.3 \%)$. 
Table 5. The public's perception of the Z.R.P's service delivery, $N=73$.

\begin{tabular}{|c|c|c|c|c|c|c|}
\hline Variable & $\begin{array}{c}\text { Variable } \\
\text { Description }\end{array}$ & $\begin{array}{c}\text { Very Poor } \\
(\%)\end{array}$ & Poor (\%) & Average (\%) & Good (\%) & $\begin{array}{c}\text { Very Good } \\
(\%)\end{array}$ \\
\hline \multirow{3}{*}{$\begin{array}{l}\text { Area of } \\
\text { residence }\end{array}$} & Bindura & 10.8 & 13.5 & 43.2 & 29.7 & 2.7 \\
\hline & Mt. Darwin & 10.3 & 13.8 & 27.6 & 20.7 & 27.6 \\
\hline & Other & 0 & 66.7 & 16.7 & 16.7 & 0 \\
\hline \multirow{5}{*}{ Age Range } & Less than 25 years & 0 & 0 & 45.5 & 45.5 & 9 \\
\hline & 26-35 years & 16.7 & 13.3 & 36.7 & 20.0 & 13.3 \\
\hline & $36-45$ years & 10.5 & 36.8 & 26.3 & 26.3 & 0 \\
\hline & 46-55 years & 0 & 33.3 & 33.3 & 16.7 & 16.7 \\
\hline & 55 years and above & 0 & 0 & 33.2 & 16.7 & 50 \\
\hline \multirow{4}{*}{$\begin{array}{l}\text { Period of } \\
\text { stay at } \\
\text { residence }\end{array}$} & Less than 1 year & 50 & 0 & 50 & 0 & 0 \\
\hline & $1-3$ years & 20 & 15 & 40 & 20 & 5 \\
\hline & 4-6 years & 7.7 & 15.4 & 53.8 & 23.1 & 0 \\
\hline & 7 years and above & 2.7 & 21.6 & 24.3 & 29.7 & 21.6 \\
\hline
\end{tabular}

Some of the respondents could have witnessed the style of policing in the pre-independence era and during the state of emergency. This possibly explains why the age group of 55 years and above considered Z.R.P's service delivery to be mainly good. The prevailing policing environment could be better than the environment that characterised the pre-independence era and during the state of emergency soon after the 1980 independence. The success of policing may also possibly be judged by the peaceful atmosphere that prevails in a country and the peaceful environment could be a testimony of good policing. We should, however, note the fact that zero tolerance policing (Grabosky 1999) also results in a peaceful environment, though this style of policing may be shrouded with illegalities. In spite of the various implications of police abuse of powers, most members of the public are still willing to assist the police in carrying out their duties. Table 6 indicates that $76.1 \%$ of the public is willing to assist the police in carrying out their duties.

Table 6. The response to whether the respondent is willing to assist the police in carrying out their duties.

\begin{tabular}{ccc}
\hline Response & Frequency & Percent \\
\hline Yes & 54 & 76.1 \\
No & 17 & 23.9 \\
Total & 71 & 100.0 \\
\hline
\end{tabular}

This supports the point that the public has maintained some confidence in the Z.R.P. The Service Charter, as indicated by some police respondents, could be the major reason why the public has retained confidence in the police. The Service Charter is re-launched in all the county's policing provinces every year and during the re-launch, the public is given a platform to interact with the police. Interviewed respondents also indicated that the public has also sponsored police activities such as sports and the officer of the month awards.

\subsubsection{Ameliorating Strategies to Police Abuse of Powers: The Public's View}

In Table 7 , the study revealed that $81.4 \%$ of the respondents perceived the training of police officers on human rights as the most effective way of reducing police abuse of powers and functions. Dealing decisively with perpetrators was considered by $79.7 \%$ of the respondents, as the most effective method. Use of the media was chosen by $76.8 \%$ of the respondents. All the remaining recommendations were considered most effective by less than $50 \%$ of the respondents. 
Table 7. The response on ameliorating strategies and recommendations, $N=73$.

\begin{tabular}{cc}
\hline Recommendation & \\
\hline Repealing/Amending bad laws & $37.7 \%$ \\
Increasing period of training & $23.2 \%$ \\
Training police officers on human rights & $81.4 \%$ \\
Proper screening during recruitment & $42 \%$ \\
Dealing decisively with perpetrators & $79.7 \%$ \\
Human rights education for the public & $45.7 \%$ \\
Use of media to expose abuse of power & $76.8 \%$ \\
Explain complaints procedure to the public & $42.9 \%$ \\
\hline
\end{tabular}

Most of the respondents who were interviewed also cited training as a measure to reduce police abuse of powers and functions. Most of them highlighted that the only cure for the lack of knowledge is the acquiring of that knowledge and that the knowledge can only be acquired through training. Respondents also indicated that the police should deal decisively with perpetrators. One of the respondents who had a legal background highlighted the need to urgently initiate criminal proceedings before disciplinary proceedings where police officers are implicated in misbehaviour that constitutes criminal offences. Some suggested immediate dismissal of implicated police officers, which the researcher considered to be contrary to the principles of natural justice. In this regard, The Commissioner General of Police has, on several occasions, reiterated that there is no room for rogue elements in the Z.R.P.

The media has become the mouthpiece for exposing police abuse of powers and the respondents also reiterated the importance of the media in curbing police abuse of powers and functions. Exposure of incidents of abuse has often brought positive reciprocal action by the police command as they would be forced to provide apologies and inform the nation on the course of action to be taken. Most of the incidents are exposed by the independent media. Some respondents were not aware of the complaints procedure in the Z.R.P, hence, they needed the Z.R.P to explain the complaints procedure. Some respondents who were, however, aware of the procedure had no faith in the procedure. They accused the police command of not taking proper action. This resonates with the study by Weisburd et al. (2000) when they discovered that, at times, police officers ignore improper conduct by their fellow officers. Dharmapala and Miceli (2012, p. 5) also found out that police officers who engage in wrongful conduct may be protected by those who do not.

Repealing and amendment of laws was mentioned in most of the in-depth interviews, though not as much on the questionnaire. One human rights activist remarked that, as long as the draconian laws are in place, the police will always find a scapegoat for their disregard for fundamental human rights. Some of the police officers also blamed the legislature for the laws which are controversial. Human rights education for the public was also suggested and respondents were of the view that this will result in more exposure of police abuse. The public indicated that they are least concerned with the period of training, as shown by the low number of respondents who considered increasing the period of training as most effective. Following the above, members of the public were asked on whom they would consider appropriate to monitor police actions in order to curb police abuse of powers and functions. As revealed in Table 8, 35.2\% of the respondents indicated that the Human Rights Commission should monitor police actions, $29.6 \%$ prefer police actions to be monitored by superior officers, while $11.3 \%$ of the respondents trusted courts and internal police monitoring unit. NGOs and the Police Service Commission were considered as the least favourable institutions for monitoring police actions. 
Table 8. The responses on who should be responsible for monitoring police actions.

\begin{tabular}{ccc}
\hline Designations & Frequency & Percent \\
\hline Superior officers & 21 & 29.6 \\
NGOs & 4 & 5.6 \\
Human Rights Commission & 25 & 35.2 \\
Courts & 8 & 11.3 \\
Internal police monitoring unit & 8 & 11.3 \\
Police Service Commission & 5 & 7.0 \\
Total & 71 & 100.0 \\
\hline
\end{tabular}

Non-Governmental Organisations (NGO).

This result indicates that citizens have more faith in an independent monitoring unit, preferably the Human Rights Commission. The Commission is established in terms of Section 242 of the Constitution of Zimbabwe. The notable functions of the Commission as enshrined in the Constitution are;

1. To monitor, assess, and ensure observance of human rights and freedoms.

2. To receive and consider complaints from the public and to take such action in regard to the complaints as it considers appropriate.

3. To protect the public against abuse of power and maladministration by State and public institutions and by officers of those institutions.

The Z.R.P., thus, falls under the scrutiny of the Commission by virtue of the organisation being a public institution. The challenge, however, which was noted by two interview respondents, is the lack of clearly defined enforcement mechanisms for the Human Rights Commission. The Commission, which was established in 2010, is fairly new and the public is yet to evaluate whether the Commission will be effective. This leaves the option of monitoring by superior officers as the most viable, though a question should be asked, "who will monitor the monitors (Superior officers)". The Z.R.P has enforcement mechanisms for dealing with police misconduct. These mechanisms are found in the Police Act and various regulations such as the Police Standing Orders. It seems the challenge of the police falls on the will to implement the mechanisms that are at their disposal.

The courts have become handy in the monitoring process. Cases have been decided to pertain to the violation of accused persons' rights. The new Constitution introduced the Constitutional Court and cases of violation of rights are now being heard with speed. The Z.R.P's internal monitoring unit, Police Internal Security Intelligence, was considered by police respondents to be a useful mechanism, as they claimed that the unit has often unearthed police misconduct. The public is, however, not aware of this police section, thus justifying why it was not considered most effective.

\subsubsection{The Z.R.P's Internal Strategies and Measures in Dealing with Police Abuse of Powers}

These measures were obtained from the in-depth interviews with police officers. The most dominant measure was the disciplinary procedure that is taken when police officers engage in various forms of misconduct. They indicated that those who breach the police code of conduct are tried by senior police officers who are of or above the rank of Superintendent. Those convicted would be sent to detention barracks or ordered to pay fines. The Police Internal Security Intelligence (PISI) also monitors police officers for misconduct such as corruption and abuse of power. Respondents also highlighted that this important department of the police gathers evidence of police abuse of powers as well as the setting up of traps in order to weed the organisation of undesirable elements. However, the challenge of monitoring still remains as both PISI and senior officers also need monitoring. Findings also revealed that refresher courses are done at the Professional Updating Centre (P.U.C) which is the provincial training wing. Some of the courses which are run by the training institution include the station tutor course, crime investigations course, traffic investigations course, and induction courses for newly promoted Sergeants. The training wing also has a research department which conducts the training 
needs analysis for police officers throughout the whole province. Most of the police officers indicated that their main source of information on human rights was the refresher courses at P.U.C.

Findings also revealed that the Z.R.P is running various educational programmes at its Staff College and local universities to equip police officers with relevant policing skills. The Police Staff College is also offering various Diploma courses for police officers who would be drawn from all the provinces. The organisation is also seconding police officers to various universities for programmes such as Law and Police Studies. Stressing on the need for having enlightened police officers on the launch of the policing degree at Bindura University, the then Commissioner General had this to say, "I would rather be arrested by a police officer who knows what he is doing than an ignoramus who poses danger not just to the innocent member of the public at his mercy, but to himself ..." ". This was an important call to have learned police officers. Police have also made use of the suggestion boxes. The public is encouraged to air their complaints through the use of suggestion boxes. However, the researcher noted some weaknesses in the use of suggestion boxes. Respondents indicated that the management of suggestion boxes falls within the public relations department and those who open them may be junior police officers. Evidence and information may be destroyed before reaching the police command. Some big police stations have a complaints desk where the public can quickly launch complaints against malperformance by police officers. The researcher, however, noted the complaints desk was not present at some of the visited police stations. Some of the police officers mentioned the yearly re-launch of the Service Charter as a positive step for improving police public relations and reducing the fear of the police. The Service Charter sets the minimum policing standards that the public should expect from the police. The publication of policy documents such as the Public Order Strategy has helped in improving police operations, especially when dealing with restive crowds. The Z.R.P has the capacity to deal with police misconduct. However, incidences of police abuse of power continue to be reported. It could be that the organisation is failing on implementation. It could also be that those charged with enforcing the mechanisms are failing or are also implicated in some of the incidences. This can also be explained by other factors such as repugnant laws which are beyond the organisation's control.

\section{Conclusions}

Findings from this study revealed that the abuse of police powers and functions impacts negatively on the police public relations. Impacts which directly relate to the police community partnership include the withdrawal of public support, loss of respect for the police, and fear of the police. Indiscriminate use of excessive force leads to loss of lives as well as injuries to innocent citizens. Civil suits, which also emanate from the abuse of police powers and functions, are both costly and detrimental to the image of the organisation. Though the Z.R.P command has put some measures to curb incidences of police abuse of power, the measures seem to be inadequate. Training, decisiveness in dealing with perpetrators, statutory amendments and creation of an independent monitoring unit are some of the measures that can be employed to curb incidences of police abuse of powers and functions. A critical evaluation of the impacts of police abuse of power will provide useful information for police policy formulation in the new political dispensation in Zimbabwe. The 'Zimbabwe is open for business' mantra of the new political dispensation necessitates the need for a paradigm shift in the way the police operate. Given the importance of the police organisation in shaping the human rights discourse - a key determinant of the country's investment climate-the Z.R.P should endeavour to uphold the citizens' rights through avoiding arbitrariness and excesses. To this end, the Z.R.P should defend, uphold, and protect the human rights of citizens as bestowed on them by the Constitution, instead of being seen as perpetrators of human rights violations in Zimbabwe. 
Author Contributions: Conceptualization and motivation of this research originated from I.M. and E.E.O. The methodological issues were done by I.M. and approved by E.E.O. While subsequent investigation and formal analysis was performed by I.M., E.E.O. ensured the validation of the instrument and research procedure. Data Curation, Writing and Original Draft Preparation was done by I.M. during his Postgraduate research, while E.E.O. was his research supervisor.

Funding: This research received no external funding.

Acknowledgments: The authors acknowledge the assistance by staff and postgraduate students of Department of Safety and Security Management, Tshwane University of Technology for their construct criticism during various seminar presentations.

Conflicts of Interest: The authors declare no conflict of interest.

\section{References}

Chihuri, Augustine. 2003. Community policing in Zimbabwe. Paper presented at the 10th AGM of International Police Executive Symposium, Bahrain City, Bahrain, October 10-18.

Chihuri, Augustine. 2015. The History of Policing in Zimbabwe-Pre-Colonial, Colonial, Post-Independence. Harare: Greatness Clinic Trust.

Chinaka, Cris. 2000. Riots in Zimbabwe as Food Prices Soar. Independent, October 17. Available online: https: / / www.independent.co.uk/news/world/africa/riots-in-zimbabwe-as-food-prices-soar-634895.html (accessed on 13 July 2018).

Dharmapala, Dhammika, and Thomas J. Miceli. 2012. Search, Seizure and (False?) Arrest: An Analysis of Fourth Amendment Remedies When Police Can Plant Evidence. Illinois Public Law Research Paper No. 13-28. University of Illinois, Champaign, IL, USA, December 5. Available online: https://ssrn.com/abstract= 2185714 (accessed on 11 July 2018).

Feltoe, Geoffrey. 1997. Report on the Internal Security Forces in Zimbabwe. Third World Legal Studies 14: 19-40, Article 3. Available online: http:/ / scholar.valpo.edu/twls/vol14/iss1/3 (accessed on 13 July 2018).

Feltoe, Geoffrey. 2012. A Guide to the Zimbabwean Law of Delict. Harare: Legal Resources Foundation.

Grabosky, Peter. 1999. Zero Tolerance Policing. In Trends and Issues in Crime and Criminal Justice. No. 102. Canberra: Australian Institute of Criminology.

Gumbo, Tatenda. 2012. Bulawayo Police Arrest 150 WOZA Activists. Voice of Zimbabwe, November 12. Available online: https:/ / www.voazimbabwe.com/a/zimbabwe-women-of-zimbabwe-arise-members-arrested/ 1544458.html (accessed on 11 July 2018).

Human Rights Watch. 2008. Our Hands are Tied: Erosion of the Rule of Law in Zimbabwe 2008. Harare: Human Rights NGO Forum.

International Bar Association. 2007. Partisan Policing: An Obstacle to Human Rights and Democracy in Zimbabwe. London: International Bar Association. Available online: http://gsdrc.org/document-library/partisanpolicing-an-obstacle-to-human-rights-and-democracy-in-zimbabwe/ (accessed on 11 July 2018).

Jessberger, Florian. 2005. Bad Torture-Good Torture? Journal of International Criminal Justice 3: 1059-73. [CrossRef] Kachere, P. 2012. Zimbabwe Republic Police must enforce Service Charter. Sunday Mail, April 1.

McCulloch, Jude, and Darren Palmer. 2003. Civil Litigation by Citizens against Australian Police between 1994 and 2002. Canberra: Australian Criminology Research Council. Available online: http://www. criminologyresearchcouncil.gov.au/reports/200102-19.html (accessed on 15 July 2018).

Omar, Ashour. 2012. From Bad Cop to Good Cop: The Challenge of Security Sector Reform in Egypt. Brookings Doha Center-Stanford University Project on Arab Transitions. Paper Series No. 3. Doha: Brookings Doha Center. Available online: https:/ / www.brookings.edu/wp-content/uploads/2016/06/Omar-Ashour-English.pdf (accessed on 13 July 2018).

Republic of Zimbabwe. 1980. The Criminal Procedure and Evidence Act [Chapter 9:07]. Harare: Government Printers. Republic of Zimbabwe. 1985. Allan v Minister of Home Affairs and Another 1985 (1) ZLR 339 (H). In Zimbabwe Law Report. Harare: Judicial Service Commission of Zimbabwe.

Republic of Zimbabwe. 1997a. Mapuranga v Mungate 1997 (1) ZLR 64 (H). In Zimbabwe Law Report. Harare: Judicial Service Commission of Zimbabwe.

Republic of Zimbabwe. 1997b. Botha v Zvada and Another 1997 (1) ZLR415 (H). In Zimbabwe Law Report. Harare: Judicial Service Commission of Zimbabwe. 
Republic of Zimbabwe. 2000a. Minister of Home Affairs and another V Bangajena 2000 (1) ZLR 306 (S). In Zimbabwe Law Report. Harare: Judicial Service Commission of Zimbabwe.

Republic of Zimbabwe. 2000b. Musadzikwa v Minister of Home Affairs and Another 2000 (1) ZLR 405 (H). In Zimbabwe Law Report. Harare: Judicial Service Commission of Zimbabwe.

Republic of Zimbabwe. 2001. Karimazondo and Another v Minister of Home Affairs and Another 2001 (2) ZLR 363 (H). In Zimbabwe Law Report. Harare: Judicial Service Commission of Zimbabwe.

Republic of Zimbabwe. 2004. Mugwagwa v Minister of Home Affairs and Commissioner of Police HH-183-2004. Harare: Judicial Service Commission of Zimbabwe.

Republic of Zimbabwe. 2010. Nyandoro v Minister of Home Affairs and Another HH-196-2010. Harare: Judicial Service Commission of Zimbabwe.

Republic of Zimbabwe. 2013a. The Constitution of Zimbabwe; Amendment (No. 20). Harare: Government Printers. Republic of Zimbabwe. 2013b. Muskwe v Minister of Home Affairs and Others HH-83-2013. Harare: Judicial Service Commission of Zimbabwe.

Skolnick, Jerome. 1999. On Democratic Policing. In Ideas in American Policing. Police Foundation Lecture Series; Washington, DC: Police Foundation, August. Available online: https:/ /www.policefoundation.org/wpcontent/uploads/2015/06/Skolnick-1999-On-Democratic-Policing.pdf (accessed on 14 July 2018).

United Nations. 1984. Convention against Torture and Other Cruel, Inhuman or Degrading Treatment or Punishment, $(C A T)$. United Nations, Treaty Series; Den Haag: International Criminal Court, vol. 1465, p. 85. December 10.

Vhiriri, Fanuel. 2011. Lest We Forget the Mugomba 13 Disaster. The Standard, September 4. Available online: https: / / www.thestandard.co.zw/2011/09/04/lest-we-forget-the-mugomba-13-disaster/ (accessed on 11 July 2018).

Weisburd, David, Roseann Greenspan, Edwin Hamilton, Kellie Bryand, and Hubert Williams. 2000. Police Attitudes towards abuse of Authority: Findings from a National Study. In United States Department of Justice. Washington, DC: Police Foundation.

Zimbabwe Human Rights Non-Governmental Organisation (NGO) Forum. 2015. Freedom from Arbitrary Arrest and Detention. Human Rights Bulletin, Number 108, July 16.

(C) 2018 by the authors. Licensee MDPI, Basel, Switzerland. This article is an open access article distributed under the terms and conditions of the Creative Commons Attribution (CC BY) license (http:/ / creativecommons.org/licenses/by/4.0/). 